\title{
Policies for the Prevention of Radical Understandings Through the Role of Community Order Supervisory Agency Police within the Indonesian National Police in Order to Improve Public Security
}

\author{
Alimuddin Sinurat ${ }^{1, *}$ Budiman Ginting ${ }^{2}$, Ediwarman $^{2}$, Mahmud Mulyadi $^{3}$ \\ ${ }^{1}$ Doctoral of Law Program, Faculty of Law, Universitas Sumatera Utara \\ ${ }^{2}$ Professor of Law, Faculty of Law, Universitas Sumatera Utara \\ ${ }^{3}$ Lecturer at Faculty of Law, Universitasa Sumatera Utara \\ Email: alimsinurat@gmail.com
}

\begin{abstract}
The role of the National Police in terms of crime prevention is to maintain the security and social order. Weak crime prevention policies are one of the factors causing the growth of radicalism in Indonesia. This paper discusses efforts to prevent radicalism through a non-penal approach that is pre-emptive by the National Police's National Security and Security Agency. This research method is normative juridical and from the results of the study, it is concluded that the non-penal approach from the pre-emptive side is much more effective and efficient to prevent people from adopting radical ideas. In carrying out efforts to prevent the development of radicalism from a pre-emptive perspective, the National Police has established Community Order Supervisory Agency Police with a focus on approaches to the community outside of the context of criminal law. However, in practice, there are still many weaknesses faced by Community Order Supervisory Agency Police. Therefore, it is hoped that this non-penal approach will be further enhanced and prioritized by the National Police by focusing on pre-emptive efforts to prevent and reduce crime, especially radicalism in Indonesia. This includes structuring the National Police of the Community Order Supervisory Agency Police institution.
\end{abstract}

Keywords: radical understanding, prevention, Police.

\section{INTRODUCTION}

\subsection{Background}

Radical understanding in Indonesia emerged based on various reasons, such as religion, politics, ideology, and others. Not only in the field of religion, but also in the fields of politics, ideology, and others as long as it is carried out using violence, including as a radical understanding. Radical opinions are common in academia where one opinion extremely opposes another.[1] But it is not justified to use violent means against people who have different understandings to actualize the religious beliefs that are adhered to by force. If an understanding is forced, using violence, against the applicable laws and regulations, then the act leads to radicalism or radicalism, namely wanting social, political, ideological, and religious changes by violent means.[2]
Radicalism in terms of religion refers to errors in thinking and understanding religious doctrines. From an ideological point of view, it seeks to change the ideology of the state according to its ideology using violence. From a social point of view, it seeks to separate itself from the unitary state as a result of social inequality. From a political point of view that is opposite to the official ideology of the state. No exception for certain political parties and mass organizations (community organizations) which are often used as bridges or means to achieve their goals of changing the ideology of Pancasila.

Radical ideology disturbs the community, threatens the security and security situation, and in turn will become a "time bomb" that threatens the lives and safety of mankind. Radicalism, if it becomes big and strong, becomes uncontrollable and leads to acts of extremism, separatism, and terrorism. They use weapons to kill people who disagree with them. Even innocent people can become victims. 
The task of the Indonesian National Police is to create security and public order, law enforcement, protection, protection, and service.[3] The National Police has changed its paradigm by forming a unit that functions to carry out non-penal approaches to the community, namely the Community Order Supervisory Agency, as a form of the Community Policing (Polmas) program in the 2005 National Police Grand Strategy.[4]

The National Police's, Community Order Supervisory Agency Unit is at the forefront of efforts to prevent radical ideas that are still on a small scale with preemptive efforts so that these radical ideas do not develop into terrorism. However, in practice, there are still many obstacles faced by the Community Order Supervisory Agency Police in supporting these pre-emptive efforts.

\subsection{Research Question}

Based on the description of the background, the problems as legal issues can be formulated as follows: How are the efforts of the Community Order Supervisory Agency Police as the front guard in preventing radical ideas from developing into terrorism.

\section{METHOD}

The type of research method used is a normative legal research method using secondary legal materials and an empirical approach. The main legal materials used are Law Number 2 of 2002 concerning the Indonesian National Police; Regulation of the Chief of Police Number 7 of 2008 concerning Basic Guidelines for Strategy and Implementation of Community Policing in Carrying Out the Duties of the National Police and Decree of the Chief of Police Number: 737/X/2005 dated October 13, 2005. Analyzing the facts and linking them with normative provisions, to arrive at a conclusion.

\section{RESEARCH RESULTS AND DISCUSS}

\subsection{Bhayangkara Supervising Public Order and Security of the Indonesian National Police}

One of the National Police's Grand Strategy in 2005 to carry out the main tasks of the National Police as a guard for public order and safety was Community Policing.[5] The orientation is to build and foster partnerships between the police and the community by prioritizing a proactive attitude and conflict resolution related to Community Order and Security.[6]

The Japan International Cooperation Agency (JICA) has been an example of the best police in the world, played by Koban and Chuzaisho.[7] Providing integrated and leading services to the community.[8] One police officer is responsible for 100 families to 500 residents. There are about 6,500 Koban in the city and 8,500 Chuzaisho in the village.[9]
Comparative studies aim to be congruent, not likely to equal the overall norm.[10] For researchers, it can provide an overview of the study of legal science for continuous improvement and expansion of the development of legal science. It is impossible to imagine jurisprudence without comparative law.[11]

Koban and Chusaizho are responsible for day-to-day security and security, 24-hour operations so that there is no time void in establishing relationships with the community. The community is also involved in all stages of police activity and works with the community to understand needs and solve problems in crime prevention.[12]

Carry out community outreach, patrols, regular visits to residents' homes. Every household is always visited and can be improved according to conditions and situational considerations. The officers met with the owner of the house and had a dialogue regarding the data of residents and their families and asked about the security situation at home and the surrounding environment, suggestions, and suggestions to the police. All recorded in a visiting card every day.

Its application in Japan has proven to be effective in raising awareness and participation of citizens in the creation of public order and security. Automatically can reduce crime rates, can detect conducive factors that can lead to criminal sources by making the surrounding community partners and friends of the police.

In Indonesia, the National Police established Community Order Supervisory Agency Police. Previously it was called Community Guidance, now it is called Community Order Supervisory Agency Police with the formation of one officer in each village. Its function is also the same as in Japan, namely being a community partner, with various social approaches, building sympathy, and interaction with the community.

In carrying out its duties, Community Order Supervisory Agency Police has the authority to make its own decisions that should not be delayed, so that the community is safe, there is no conflict, and criminogenic factors cannot develop into crimes.[13] Taking action is not bound by law,[14] but relies on personal judgment (discretion), [15] the call of conscience, [16] and wisdom in carrying out tasks according to moral demands rather than formal action.[17]

\subsection{Policy on Prevention of Radical Understanding through Preemptive Efforts}

Crime prevention includes prevention and eradication. Prevention includes pre-emptive and preventive, while eradication is carried out in a repressive way. Prevention of radical ideas can be done through preemptive and preventive efforts. In this case, Community Order Supervisory Agency Police becomes the most promising alternative in crime prevention. Because they can directly align and become community partners in 
solving daily problems, including diagnosing the factors that cause turmoil in society and the bases of radicalism.

The criminal policy doctrine proposed by Marc Ancel, Peter G. Hoefnagels,[18] Sudarto,[19] and Barda Nawawi Arief, includes criminal law application; prevention without punishment; and influencing view of society on crime and punishment. The criminal policy is part of social policy, because criminal problems cannot be separated from social problems. Talking about a better and more effective crime prevention policy is not only discussing how to tackle crime using criminal law (penal) but also non-penal efforts to prevent community behavior from continuing towards crime.[20]

The nature of prevention in non-penal efforts can be further divided into two parts, namely: first, covering all efforts outside of legal remedies (social approaches) such as coaching, counseling, skills, employment, economics, education, sports, development, partnership forums, social -culture, and others. Second, includes all legal remedies other than criminal law, such as the use of civil law and administrative law. Non-penal nature is open to all methods of any approach taken to achieve legal goals.

This approach model has been carried out by the National Police in tackling radicalism pre-emptively through the role of Community Order Supervisory Agency Police, while for prevention it is played by the Directorate for Security of Vital Objects of the Samapta Bhayangkara Corps. In tackling radical ideas in Indonesia, it must be done holistically, integrated, and systemically, by involving all existing elements, including the social strata themselves. Through the role of the National Police of Community Order Supervisory Agency, involving any means outside the norms of criminal law, if necessary, personnel must also be able to become clerics, priests, or clergy, who can reduce the forerunner (genes) of radicalism. These choices must of course optimize the role of Community Order Supervisory Agency Police which has been running but has not been satisfactory.

The main task of the Community Order Supervisory Agency Police is to create public roder and safety by approaching the community through pre-emptive efforts covering all non-penal efforts. Not looking at the conducive factors or potential vulnerability factors that can cause crime,[21] but prevention efforts are carried out long before the alleged crime, including all prevention efforts, are those that provide guidance and counseling of public legal awareness.[22]

The forms of activities of the National Police of Community Order Supervisory Agency Police in every village and sub-district include: 1) Conducting community development activities, patrols, and face-toface with residents; 2) Communicating with community members directly, or through means of communication; 3) Organizing communication forums with the community on a regular, periodic or incidental basis; 4) Approach and communication with formal and informal leaders (customary, religious, youth/women, women/mother figures, students, businessmen, and professions). This includes all citizens who are invited to actively participate in maintaining security and order; 5) Application of the concept of solving social problems by prioritizing peace; 6) Facilitating the security system in the neighborhood where they live; 7) Take advantage of the opportunity for women's social gathering and regular meetings in their area to discuss security and public order; 8) Utilize market posts to establish communication with traders and buyers, and provide information on theft and pickpocketing issues; 9) Using the organization of community activities such as football matches, music concerts, and so on and avoiding problems of security and public order.

The forms of these activities can be developed according to the needs and local wisdom that exists in the rural/urban village. In essence, these activities can increase the friendly relationship between officers and the surrounding community, reduce radical ideas, so that the goals of security and public order will also automatically be achieved to become conducive.

\subsection{Community Response to Community Order Supervisory Agency Police and Radicalism}

Many factors have developed within the community related to the understanding of radicalism and the existence of the Community Order Supervisory Agency Police, including 1) a. The smell of the power and strength of the Police is still strong in the community, causing a gap between the citizens and the Police. The efforts so far through the National Police's Community Order Supervisory Agency Police have not been deemed sufficient, because they still place personnel in positions that are not yet equal to the citizens. Residents are often placed as the fostered party and the police as coaches. Society only as object and Police as subject; 2) Society needs religious, familiar, and humanist figures who should be present in their midst as role models and places to ask questions about religious values and how to overcome various difficulties in their lives; 3) Radicalism is not always violent, extreme, and dangerous as in common thinking. However, it can become big, extreme, and even become a terrorist if it is not immediately known to be discussed in a family, humanist, and religious manner. Religious discussions and forums are highly expected by these notions, especially those that are still on a small scale (genes) because in general, they are the result of brainwashing; 4) Radical ideas generally appear among economically weak people, especially followers, while the brains of the perpetrators are generally still classified as middle to upper-class economies; 5) Society, in general, has not felt the professionalism of the Community Order Supervisory Agency Police in certain areas; 6) People often do not want to report to the police, or they prefer to remain silent, or take the law into their own hands, due to disappointment from what they see about the behaviour of Indonesian National Police personnel; 7) Some members of the community are indifferent and 
opportunistic with the Community Order Supervisory Agency Police initiative. People generally think that security and security affairs are the affairs of the police or if they need extra security for themselves and their families, they simply hire professional and trained security services. This attitude of citizens is related to the lack of socialization to understand the Polmas program and its benefits; 8) Informing the Police and Community Partnership Forum (FKPM) and the National Police and Community Partnership Center (BKPM) in general, the people chosen as partners tend to be known to be close and mingle with the Police. For those who do not know, usually, always refuse to partner with the National Police, especially if they have been traumatized by the services provided, for example in obtaining a driving license, vehicle registration certificate, etc., sometimes it becomes a bitter impression for residents who do not escape their memory; 9) Community Order Supervisory Agency Police personnel generally only request data from the Village Head or Head of Sub-District/Head of the Environment without going to the residents to collect data; 10) Often the presence of Community Order Supervisory Agency Police personnel through notification by residents. If the residents did not inform them, the personnel would not at all know what had happened, thus endangering the security and security of the community.

Many factors weaken the National Police's Community Order Supervisory Agency Police in dealing with radicalism. The pre-emptive efforts carried out by the National Police Community Order Supervisory Agency Police have not been optimal because they are still using the one village one Police method. This means that in one village only one Police officer is assigned, even for one sub-district, one officer is still found.

It is not logical for one person to be able to reach all places with a large number of residents in one village, let alone in one sub-district. As a result, they are more passive. In addition, the nature of preventing radicalism by the Police still relies on the intelligence system as a priority in a closed manner. The role of Community Order Supervisory Agency Police personnel should be transparent (open) and not peeping in nature.

Efforts to implement Community Policing are also a problem for Community Order Supervisory Agency Police itself. For example, the lack of operational and accommodation costs in monitoring all developments in the village actively, visiting or visiting, socializing, and so on. Even the salary for one Community Order Supervisory Agency Police personnel is still very low for himself and his family, causing new problems in carrying out operations carrying out daily tasks.

\subsection{Optimizing the Role of the National Police of Community Order Supervisory Agency Police in Efforts to Prevent Radicalism}

Many things must be improved according to the expectations of the community regarding the existence of the National Police of Community Order Supervisory Agency Police, among others: 1) The community should be made the subject of carrying out the duties and functions of the National Police, especially by Community Order Supervisory Agency Police; 2) The National Police should recruit Community Order Supervisory Agency Police personnel who are ready and tough in all aspects, have expertise in the fields of religion, psychology, sociology, and can solve the problems of citizens familiarly and humanely; 3) Provide personnel training before deployment; 4) Community Order Supervisory Agency Police personnel must be able to hold religious discussions and forums to avoid brainwashing. There should be changes in social and economic strata that are better, fairer, and more equitable, especially in providing job opportunities for young people so as not to become victims of brainwashing; 5) The personnel of Community Order Supervisory Agency Police in dealing with social problems must be professional, do not play with "white flour", "picky people", or violate moral hazard. This includes all members of the National Police so as not to act as unscrupulous persons when dealing with the National Police; 6) The presence of Community Order Supervisory Agency Police personnel is required as a professional and trained security guard, even like a village midwife, ready to serve residents 24 hours a day without any burden or reason; 7) So that citizens are not opportunistic, it is hoped that a total internal change from the Indonesian National Police institution itself because the perpetrators can cause distrust of the citizens in establishing partners and forums with the Community Order Supervisory Agency Police; 8) For Community Order Supervisory Agency Police personnel, they must be active from all aspects, both requesting data from the Village/Environmental/Sub-district Head, also being active in the problems faced by residents, visiting them, routine observations, and socializing, and responding quickly through a system of cooperation with the apparatus. village; 9) It is necessary to increase the personnel of Community Order Supervisory Agency Police in each village. For example, three or four or more people in one village with different capacities to fill each other's weaknesses including equipping them with the necessary facilities and infrastructure. So that it can reach all places with a large number of residents in one village, especially in one sub-district. The personnel must be active in the problems faced by the citizens to know the existence of these radical ideas; 10) There are additional incentives for Community Order Supervisory Agency Police personnel, including operational and accommodation costs in carrying out their duties so that they are active, make village visits or visits, socialize with residents, and others; 11) Optimizing the application 
of Polmas principles such as intensive communication, equality, partnership, transparency, accountability, participation, personalization, decentralization, autonomy, proactiveness, problem-solving and service orientation, must be felt by the citizens as a whole; 12) Prioritizing the principle of transparency, not with an intelligence system. This means that the presence of Community Order Supervisory Agency Police personnel must be in the midst of the community as befits a public figure or a village midwife. It is also expected that all Polmas principles must be implemented such as intensive communication, equality, partnership, transparency, accountability, participation, personalization, decentralization, autonomy, proactiveness, problemsolving, and service orientation.

\section{CONCLUSION}

Prevention of radical ideas in terms of criminal policy is more effective than eradicating. Because if it has grown into terrorism, it will require extra work, time,

\section{REFERENCES}

[1] The University of Chicago, 1965, Jeremy Bentham, A New Survey Of Universal Knowledge: Encyclopaedia Britannica, William Benthon Publisher, Chicago, p. 486.

[2] Angga N., (2016), "Faktor-Faktor Penyebab Radikalisme Dalam Beragama (Kajian Sosiologi Terhadap Pluralisme Agama Di Indonesia)", Jurnal Al-AdYaN, Vol.XI, (1), Januari-Juni, hlm. $1-19$.

[3] Undang-Undang No. 2 Tahun 2002 Tentang Kepolisian Republik Indonesia.

[4] Peraturan Kepala Kepolisian Negara Republik Indonesia Nomor 7 Tahun 2008 Tentang Pedoman Dasar Strategi Dan Implementasi Pemolisian Masyarakat Dalam Penyelenggaraan Tugas Polri.

[5] Surat Keputusan Kepala Polri Nomor: 737/X/2005 Tanggal 13 Oktober 2005.

[6] Dominique W., \& Ihekwoaba D.O., (2007), "Community Policing: A Comparative View, International Police Executive Symposium Geneva Centre For The Democratic Control Of Armed Forces", IPES Working Paper, 6, May, pp. 3-26.

[7] Monica T., \& Ahsan J.H., 2009, Program Pemolisian Masyarakat, Institute for Defense Security and Peace Studies (IDSPS) Press, Jakarta, pp. 1-5.

[8] Satjipto R., 2002, Membangun Polisi Sipil, Perspektif Hukum, Sosial, dan Kemasyarakatan, Kompas Media Nusantara, Jakarta, hlm. 95. money, energy, thoughts, and even impact on victims. The performance of Community Order Supervisory Agency Police so far has not been effective in preventing radical ideas. There are still many weaknesses that require improvement in supporting their task of carrying out non-penal efforts (pre-emptive and preventive) in a holistic manner.

It is hoped that the National Police's Community Order Supervisory Agency Police will be improved, including the Indonesian National Police institution itself and its personnel as a whole, especially the negative cultures that have also become a dividing factor between the citizens and the Police. The alternative to optimizing Community Order Supervisory Agency Police must be placed as a non-negotiable option in reducing radicalism so that it does not grow into terrorism, extremism, and separatism.

[9] Monica T., \& Ahsan J.T., 2009, Program Pemolisian Masyarakat, Institute for Defense Security and Peace Studies (IDSPS) Press, Jakarta, p. 2.

[10] Werner M., 2008, Comparative Law in a Global Context, Cambridge University Press, United Kingdom, diterjemahkan Khozim, M., 2016, Perbandingan Hukum Dalam Konteks Global, Sistem Eropa, Asia dan Afrika, Nusa Media, Bandung, hlm. 57.

[11] Peter de C., 1999, Comparative Law in a Changing World, Cavendish Publishing Limited, London-Sydney, diterjemahkam Yusron, Narulita., 2016, Perbandingan Sistem Hukum, Common Law, Civil Law and Socialist Law, Nusa Media, Bandung, hlm. 503.

[12] Sadjijono, 2005, Fungsi Kepolisian Dalam Pelaksanaan Good Governance, Laksbang, Yogyakarta, hlm. 1-2.

[13] Mulyadi, M., dan Sujendral, A., 2011, Community Policing: Diskresi Dalam Pemolisian Yang Demokratis, Sofmedia, Medan, hlm. 3.

[14] Darminto, 1998, Buku Pelajaran Tugas Umum Kepolisian, Berdasarkan Surat Keputusan Direktur Pendidikan Polri No. Pol. SKEP/05/II/1988 Tentang Pengesahan Buku Pelajaran Tugas Umum Kepolisian, Markas Besar Kepolisian Negara Republik Indonesia Direktorat Pendidikan, Jakarta, hlm. 131.

[15] Soerjono S., 2002, Faktor-Faktor yang Mempengaruhi Penegakan Hukum, RajaGrafindo Persada, Jakarta, hlm. 15.

[16] Howard A., 1984, Discretionary Justice, An Introduction to Discretion in Criminal Justice, 
Charles C. Thomas Publisher, SpringfieldAmerika Serikat, p. 3.

[17] Paul B.W., 1965, Supervision in The Administration of Justice Police, Coorection, Courts, Charles \& Thomas, Springfield, p. 129. Lihat juga: Marwan E., 2012, Diskresi, Penemuan Hukum, Korporasi \& Tax Amnesty Dalam Penegakan Hukum, Referensi, Jakarta, hlm. 6.

[18] G. Peter H., 1969, The Other Side of Criminology, An Inversion of The Concept of Crime, Kluwer Academic Publisher, Holland, p. 57.

[19] Sudarto, 2006, Kapita Selekta Hukum Pidana, Alumni, Bandung, hlm. 113-114. Lihat juga:
Suharto, Edi., 2005, Analisis Kebijakan Publik, Alfa Beta, Bandung, hlm. 7.

[20] Barda N.A., 2011, Bunga Rampai Kebijakan Hukum Pidana: Perkembangan Penyusunan Konsep KUHP Baru, Kencana, Jakarta, hlm. 40.

[21] Soerjono S., 2002, Faktor-Faktor Yang Mempengaruhi Penegakan Hukum, Raja Grafindo Persada, Jakarta, hlm. 15.

[22] Mulyadi, M., 2008, Criminal Policy, Pendekatan Integral Penal Policy dan Non-Penal Policy Dalam Penanggulangan Kejahatan Kekerasan, Pustaka Bangsa Press, Medan, hlm. 144. 